University of Nebraska - Lincoln

DigitalCommons@University of Nebraska - Lincoln

Faculty Publications: Department of

Entomology

Entomology, Department of

1998

Random Amplified Polymorphic DNA Used to Identify Genetic

Variation in Ecotypes of the European Corn Borer (Lepidoptera:

Pyralidae)

\author{
Saowaluck Pornkulwat \\ University of Nebraska-Lincoln \\ Steven R. Skoda \\ USDA-ARS-KBUSLIRL Screwworm Research Unit, Steve.Skoda@ars.usda.gov \\ Gustave D. Thomas \\ University of Nebraska-Lincoln \\ John E. Foster \\ University of Nebraska-Lincoln, john.foster@unl.edu
}

Follow this and additional works at: https://digitalcommons.unl.edu/entomologyfacpub

Part of the Entomology Commons

Pornkulwat, Saowaluck; Skoda, Steven R.; Thomas, Gustave D.; and Foster, John E., "Random Amplified Polymorphic DNA Used to Identify Genetic Variation in Ecotypes of the European Corn Borer (Lepidoptera: Pyralidae)" (1998). Faculty Publications: Department of Entomology. 554.

https://digitalcommons.unl.edu/entomologyfacpub/554

This Article is brought to you for free and open access by the Entomology, Department of at DigitalCommons@University of Nebraska - Lincoln. It has been accepted for inclusion in Faculty Publications: Department of Entomology by an authorized administrator of DigitalCommons@University of Nebraska - Lincoln. 


\title{
Random Amplified Polymorphic DNA Used to Identify Genetic Variation in Ecotypes of the European Corn Borer (Lepidoptera: Pyralidae)
}

\author{
SAOWALUCK PORNKULWAT, ${ }^{1}$ STEVEN R. SKODA, ${ }^{2}$ GUSTAVE D. THOMAS ${ }^{2}$ AND JOHN E. FOSTER ${ }^{1}$
}

Ann. Entomol. Soc. Am. 91(5): 719-725 (1998)

\begin{abstract}
The European corn borer, Ostrinia nubilalis (Hübner), has 3 morphologically indistinguishable voltinism ecotypes. Random amplified polymorphic DNA-polymerase chain reaction (RAPD-PCR) was used to discriminate ecotypes of the European corn borer. Genomic DNA samples from the European corn borer were screened with a total of 120 random primers. Ten of these primers yielded 21 clear and reproducible RAPD markers after agarose gel electrophoresis. Dendrograms constructed using the Nei and Li distance matrix of the phylogenetic relationships, among and within ecotypes, of the European corn borer showed the multivoltine ecotype to be genetically separated from univoltine and bivoltine ecotypes. The dendrogram of individual European corn borers correctly classified each insect. These results provide evidence of genetic variation at the molecular level among European corn borer ecotypes. The RAPD-PCR technique proved to be a powerful tool for identifying intraspecific variation in the European corn borer.
\end{abstract}

KEY WORDS European corn borer, random amplified polymorphic DNA-polymerase chain reaction, molecular genetics

THE EUROPEAN CORN borer, Ostrinia nubilalis (Hübner), one of the most destructive pests of corn in the Midwest, has been present in North America since $\approx 1917$ (Metcalf and Metcalf 1993). In North America, there are 3 voltinism ecotypes (Showers et al. 1975). In the northern United States and Canada, 1 generation per year (univoltine) occurs; the central United States has 2 generations per year (bivoltine), and 3 or more generations per year (multivoltine) occur in the southern United States (Mason et al. 1996). A study of gene flow among races of European corn borer in New York (Glover et al. 1991) suggested that European corn borer ecotypes have life history differences of considerable importance for effective monitoring and control programs, and that these differences have genetic bases.

In addition to ecotype differences, European corn borer populations differ distinctly in their sex pheromone communication systems (Glover et al. 1992). Sexual communication based on pheromones leads to mating between individuals sharing similar alleles at loci determining female pheromone production and male response (Bengtsson and Löfstedt 1990). Two pheromone strains of the European corn borer, the $\mathrm{E}$ and $\mathrm{Z}$ strains, occur in North America and Europe (Klun et al. 1975). Klun and Maini (1979) showed that

This article reports the results of research only. Mention of a proprietary product does not constitute endorsement or recommendation by USDA for its use.

' Department of Entomology, University of Nebraska-Lincoln, Lincoln, NE 68583-0816.

${ }^{2}$ Midwest Livestock Insects Research Laboratory, USDA-ARS, University of Nebraska-Lincoln, Lincoln, NE 68583-0938. the geometric composition of the female European corn borer sex pheromone is controlled by simple Mendelian inheritance involving a single pair of alleles at a single autosomal locus (Zhu et al. 1996). Glover et al. (1992) reported that European corn borer postdiapause developmental time, an essential component of voltinism, is controlled by a gene(s) on the sex chromosomes ( $\mathrm{Z}$ chromosomes). Although the populations are morphologically indistinguishable, studies of allozymes, pheromones, and hybridization suggest that the $\mathrm{Z}$ and $\mathrm{E}$ entities are genetically differentiated, perhaps to the status of semi- or sibling species (Cardé et al. 1978).

Genetic interaction among voltinism has not been extensively studied. Molecular markers offer many options to differentiate intra- and interspecific populations. The molecular technique, random amplified polymorphic DNA (RAPD), uses single, short, arbitrary primers in genomic DNA amplification by the polymerase chain reaction (PCR) to detect polymorphisms (Welsh and McCelland 1990, Williams et al. 1990). This technique requires only minute amounts of DNA template, no sequence information, and no radioactivity. RAPD-PCR makes it possible to identify hundreds of new genetic markers in a short time, allowing genetic maps as well as DNA fingerprints to be developed rapidly (Ragot and Hoisington 1993). RAPD-PCR is particularly valuable for genome mapping in species for which little genetic information is available (Hoy 1994) such as the European corn borer. Our objective was to use the RAPD technique to differentiate European corn borer populations with different voltinism ecotypes. 


\section{Materials and Methods}

Insects. European corn borer larvae were collected from areas assumed to represent populations of unique voltinism (Mason et al. 1996). Larvae collected from Grand Forks, ND, represented the univoltine population; Constantine, MI, bivoltine; and Unionville, TN, multivoltine populations. Larvae were field collected in the fall of 1995 from seed corn fields in these areas, brought to the laboratory, surface sterilized, and maintained on a meridic diet (CIMMYT 1987) at a photoperiod of 8:16 (L:D) h and a constant temperature of $25^{\circ} \mathrm{C}$. Late instars were then collected and individually stored in $1.5 \mathrm{ml}$ tubes at $-80^{\circ} \mathrm{C}$.

DNA Isolation. Total genomic DNA was isolated from late instars. The insect gut was removed, the larvae were placed individually in 1.5-ml Eppendorf tubes, ground in $50 \mu$ l of sterile double distilled water, and centrifuged at $10,000 \times g$ for $10 \mathrm{~min}$. The upper aqueous phase was discarded. Fifty microliters of Nonidet P-40 (NP-40) and $50 \mu \mathrm{l}$ of stock buffer $(100 \mathrm{mM}$ $\mathrm{NaCl}, 100 \mathrm{mM}$ Tris $\mathrm{HCl}, 100 \mathrm{mM}$ EDTA) were added. Samples were centrifuged again and the supernatant discarded. Ice-cold lysis buffer (2.5\% SDS in stock buffer) and $1 \mathrm{mg}$ of proteinase $\mathrm{K}$ were added into the tubes. The tubes were incubated at $56^{\circ} \mathrm{C}$ for $2 \mathrm{~h}$, and held at $37^{\circ} \mathrm{C}$ overnight. The next day RNAase was added 2-4 h prior to phenol/chloroform extraction. The DNA solution was precipitated in $95 \% \mathrm{EtOH}$ and kept overnight at $-20^{\circ} \mathrm{C}$. The DNA pellet was collected and resuspended with $50 \mu$ l of TE buffer the next day.

Polymerase Chain Reaction. After evaluating Perkin Elmer GeneAmp PCR System 9600, 2400, and Thermal cycler 480, all PCRs were performed using the Perkin-Elmer GeneAmp PCR System 9600. Reagents used for PCR were obtained from Perkin-Elmer Cetus Corporation (Norwalk, CT) unless otherwise noted. Fifteen DNA samples from 3 ecotypes were used for initial screening. Another 15 DNA samples from each ecotype were used to confirm RAPD markers; each primer was replicated at least 5 times. Each DNA sample was diluted in sterile distilled water in a ratio of 1:10, 1:20, 1:50, and 1:100 (DNA:water) for optimization purposes. The 1:20 dilution $(2.5 \mathrm{ng} / \mu \mathrm{l})$ gave the best result for most primers used and we used it for the rest of the procedure. Other optimized amplification parameters included incremental (0.5) increases in the amount of $\mathrm{MgCl}_{2}$ from 0.5 to $5 \mathrm{mM}$; incremental increases $(1 \mu \mathrm{l})$ in each dNTPs $(10 \mathrm{mM})$ from 1 to $5 \mu \mathrm{l}$; oligonucleotide primer concentrations from 100 to 400 pmoles (in 100-pmole increments); AmpliTaq DNA Polymerase Stoffel fragment $(10 \mathrm{U} / \mu \mathrm{l})$ from 1 to 5 units (in 1-unit increments); and temperature profiles (different annealing temperatures, cycles, and times).

The incubated PCR tubes and all micropipettes were surface sterilized with UV before use. The PCR was carried out in a total volume of $25 \mu \mathrm{l}$. A master mix consisted of each of the following components (multiplied by the total number of tubes): $12.2 \mu \mathrm{l}$ of sterile distilled water, $1 \mu \mathrm{l}$ of $1 \%$ Nonidet P-40, $2.5 \mu \mathrm{l}$ of $10 \times$
Stoffel Buffer, $3 \mu$ of dNTPs ( $10 \mathrm{mM}$ of each dATP, dCTP, dGTP, dTTP), $4 \mu \mathrm{l}$ of $25 \mathrm{mM} \mathrm{MgCl}_{2}, 1 \mu$ l of each diluted DNA sample (1:20), and $0.3 \mu$ l of AmpliTaq DNA Polymerase Stoffel fragment. Samples were mixed gently, spun down for $\approx 5 \mathrm{~s}$, and $24 \mu \mathrm{l}$ of the master mix was aliquoted to individual tubes. One hundred picomoles $(1 \mu \mathrm{l})$ of each 10-mers primer (Operon, Alameda, CA) was then added to the appropriate tube. A negative control (all PCR mix except DNA template) was added to check whether there was contamination.

The following temperature profile was used: an initial denaturation at $95^{\circ} \mathrm{C}$ for $5 \mathrm{~min}, 10$ cycles of $94^{\circ} \mathrm{C}$ for $1 \mathrm{~min}, 36^{\circ} \mathrm{C}$ for $30 \mathrm{~s}$, and $72^{\circ} \mathrm{C}$ for $1 \mathrm{~min}$, followed by 30 cycles of $94^{\circ} \mathrm{C}$ for $10 \mathrm{~s}, 35^{\circ} \mathrm{C}$ for $30 \mathrm{~s}$, and $72^{\circ} \mathrm{C}$ for $30 \mathrm{~s}$. An additional extension step of $72^{\circ} \mathrm{C}$ for $5 \mathrm{~min}$ was done. Approximately $14 \mu \mathrm{l}$ of the PCR products was loaded on $2.0 \%$ Ultrapure Agarose Gel (GibcoBRL, Gaithersburg, MD) and electrophoresed at 100 $\mathrm{V}$ for $3.5 \mathrm{~h}$. One-kilobase and 50-bp ladders (GibcoBRL) were used as molecular weight markers. The gel was then stained in $0.5 \mu \mathrm{g} / \mathrm{ml}$ of ethidium bromide solution for $15 \mathrm{~min}$ and photographed.

Data Analysis. Photographs of the gels were scanned by HP ScanJet IIcx (Hewlett-Packard, Greeley, $\mathrm{CO}$ ). Only the most visible and reproducible bands were used as markers (Roderick 1996) and scored as present or absent by values of 1 and 0 , respectively. Primers that generated many bands with banding patterns so complex that scoring was made difficult, were eliminated (Schnell et al. 1996). DNA ProScore (DNA ProScan, Nashville, TN) was used to mark the RAPD bands with respect to the molecular weight markers presented on the agarose gels. RAPDistance version 1.04 (John Armstrong et al., Australian National University, Canberra, Australia) was used to estimate within-group distances. A distance matrix was calculated based on the Nei and $\mathrm{Li}$ (1979) formula: $F=2 N_{x y} /\left(N_{x}+N_{y}\right)$ in which $N_{x}$ and $N_{y}$ are the numbers of RAPD fragments generated in populations $\mathrm{X}$ and $\mathrm{Y}$, respectively, whereas $N_{x y}$ is the number of fragments shared by the 2 populations. The index $F$, expressed as a percentage, ranges from 0 (no shared bands) to $100 \%$ (identical bands in $\mathrm{X}$ and $\mathrm{Y}$ ). The Neighbor program in Phylip 3.5c (Felsenstein 1989) was used to construct a within-group dendrogram from the $F$ values by using the unweighted pair group using arithmetic averages. Then, the Gendist program from Phylip 3.5c (Felsenstein 1989) was used to estimate among-group distances (using the proportion of fragments in each ecotype based on the formula of Nei [1972]) and the Neighbor program was used to construct a 2nd dendrogram that separated ecotypes of European corn borer.

\section{Results}

We compared 3 Perkin-Elmer thermal cyclers, GeneAmp PCR system 9600, 2400, and Thermal Cycler 480 . The ramp time of Thermal Cycler 480 is longer than that of the other thermal cyclers. This caused some variation in the RAPD banding pat- 
Tuble 1. List of all arbitrary 10-mer primers and sequences used to produce RAPD markers for the European corn borer

\begin{tabular}{lc}
\hline \hline Primer & Sequence \\
\hline OPA-05 & AGGGCTCTTG \\
OPA-07 & GAAACGGGTG \\
OPA-16 & AGCCAGCGAA \\
OPB-01 & GTTTCGCTCC \\
OPB-08 & GTCCACACGG \\
OPC-15 & GACGGATCAG \\
OPC-18 & TGAGTGGGTG \\
OPD-11 & AGCGCCATTG \\
OPF-01 & ACGGATCCTG \\
OPF-03 & CCTGATCACC \\
\hline
\end{tabular}

terns. Only the GeneAmp PCR system 9600 was used to reduce the problem of variation among different machines. From a total of 120 primers (OPA01-20, OPB01-20, OPC01-20, OPD01-20, OPE01-20, OPF01-20) initially screened on 15 European corn borer samples, 10 primers (OPA-05, OPA-07, OPA-16, OPB-01, OPB-08, OPC-15, OPC18, OPD-11, OPF-01, OPF-03) (Table 1) generated potential RAPD markers. Individual DNA bands were scored as present (1) or absent (0) in the banding pattern of an individual insect; only clearly amplified and reproducible DNA bands in all replications were selected and scored (a total of 21 bands). Table 2 shows the portion of RAPD fragments amplified from the 10 primers in individuals from the 3 different ecotypes of the European corn borer: some primers showed fragments that were unique to an ecotype, and other fragments were conserved for all individuals of European corn borers tested. The distance matrix, calculated using data from 21 markers found within 10 primers (Table 3), presents the expected proportion of dissimilarity between pairs of individual European corn borer. The most genetically similar individuals exhibit a low distance matrix index whereas the high distance matrix indices indicate less relationship between the compared individuals. The OPB-01 primer, one of the most informative, gives 4 markers that appear to separate univoltine and bivoltine from multivoltine and shows 1 conserved band ( 372 bp) for all European corn borer individuals (Fig. 1). Dendrograms of relationships within (Fig. 2) and among (Fig. 3) European corn borer ecotypes show that RAPD markers correctly separated the ecotypes. The distance between univoltine and bivoltine (cluster) appears to be much less than that of both or either ecotype to multivoltine (Fig. 3).

\section{Discussion}

Little genetic information is known for the European corn borer in general and even less is known about multivoltine European corn borers. DNA fingerprinting, using arbitrary primed PCR, is a versatile method for detecting polymorphisms. Our results from RAPD patterns presented here confirm the divergence of the different ecotypes at the molecular level (Table 2) and indicate that RAPD-PCR may be useful for differentiating intraspecific variation of the European corn borer. Our results from RAPD-PCR show multivoltine separated from the univoltinebivoltine cluster. The dendrograms confirmed a high degree of relatedness between univoltine and bivoltine in comparison to multivoltine. This can be explained by considering when European corn borer was thought to have been 1st introduced into North America in the vicinity of Boston in 1917 (Caffrey and Worthley 1927). Which ecotype was 1st introduced into the United States is unknown. Also, it is unknown if there was a single or multiple introductions. Since the first introduction(s) of the European corn borer, it appears enough time has passed for the multivoltine ecotype to be separated from univoltine and bivoltine, as shown in our dendrogram. Most of the RAPD mark-

Tuble 2. The portion of 21 RAPD fragments (mean \pm SEM) amplified from 10 primers in each ecotype of European corn borer

\begin{tabular}{|c|c|c|c|c|}
\hline Primer & Size, bp & Univoltine & Bivoltine & Multivoltine \\
\hline \multirow[t]{3}{*}{ OPA-05 } & 649 & $0.6 \pm 0.2$ & $1.0 \pm 0.0$ & $0.6 \pm 0.2$ \\
\hline & 463 & $1.0 \pm 0.0$ & $1.0 \pm 0.0$ & $1.0 \pm 0.0$ \\
\hline & 273 & $1.0 \pm 0.0$ & $1.0 \pm 0.0$ & $1.0 \pm 0.0$ \\
\hline \multirow[t]{3}{*}{ OPA-07 } & 629 & $1.0 \pm 0.0$ & $0.0 \pm 0.0$ & $0.0 \pm 0.0$ \\
\hline & 529 & $1.0 \pm 0.0$ & $1.0 \pm 0.0$ & $1.0 \pm 0.0$ \\
\hline & 263 & $1.0 \pm 0.0$ & $1.0 \pm 0.0$ & $0.6 \pm 0.2$ \\
\hline \multirow[t]{2}{*}{ OPA-16 } & 504 & $1.0 \pm 0.0$ & $0.6 \pm 0.2$ & $0.0 \pm 0.0$ \\
\hline & 489 & $0.0 \pm 0.0$ & $0.0 \pm 0.0$ & $1.0 \pm 0.0$ \\
\hline \multirow[t]{5}{*}{ OPB-0I } & 977 & $0.6 \pm 0.2$ & $0.2 \pm 0.2$ & $1.0 \pm 0.0$ \\
\hline & 875 & $1.0 \pm 0.0$ & $1.0 \pm 0.0$ & $0.0 \pm 0.0$ \\
\hline & 559 & $0.6 \pm 0.2$ & $1.0 \pm 0.0$ & $0.2 \pm 0.2$ \\
\hline & 372 & $1.0 \pm 0.0$ & $1.0 \pm 0.0$ & $1.0 \pm 0.0$ \\
\hline & 331 & $1.0 \pm 0.0$ & $0.8 \pm 0.2$ & $0.0 \pm 0.0$ \\
\hline \multirow[t]{2}{*}{ OPB-OS } & 677 & $0.6 \pm 0.2$ & $0.4 \pm 0.2$ & $1.0 \pm 0.0$ \\
\hline & 260 & $1.0 \pm 0.0$ & $1.0 \pm 0.0$ & $1.0 \pm 0.0$ \\
\hline OPC-15 & 233 & $1.0 \pm 0.0$ & $0.6 \pm 0.2$ & $0.0 \pm 0.0$ \\
\hline OPC-18 & 495 & $0.0 \pm 0.0$ & $0.2 \pm 0.2$ & $1.0 \pm 0.0$ \\
\hline OPD-11 & 787 & $1.0 \pm 0.0$ & $1.0 \pm 0.0$ & $0.0 \pm 0.0$ \\
\hline \multirow[t]{2}{*}{ OPF-01 } & 738 & $0.2 \pm 0.2$ & $1.0 \pm 0.0$ & $0.0 \pm 0.0$ \\
\hline & 298 & $1.0 \pm 0.0$ & $1.0 \pm 0.0$ & $1.0 \pm 0.0$ \\
\hline OPF-03 & 602 & $0.2 \pm 0.2$ & $0.8 \pm 0.2$ & $1.0 \pm 0.0$ \\
\hline Mean $\pm S E M$ & & $0.7523 \pm 0.0791$ & $0.7428 \pm 0.0794$ & $0.5904 \pm 0.1027$ \\
\hline
\end{tabular}


Table 3. A distance matrix computed for individual European corn borers from each ecotype by using the method of Nei and li (1979)

\begin{tabular}{|c|c|c|c|c|c|c|c|c|c|c|c|c|c|c|c|}
\hline & $\mathrm{Ml}$ & M2 & M3 & M4 & M5 & U1 & U2 & U3 & U4 & U5 & B1 & B2 & B3 & B4 & B5 \\
\hline Ml & 0 & & & & & & & & & & & & & & \\
\hline M2 & 0.083 & 0 & & & & & & & & & & & & & \\
\hline M3 & 0.000 & 0.083 & 0 & & & & & & & & & & & & \\
\hline M4 & 0.120 & 0.040 & 0.120 & 0 & & & & & & & & & & & \\
\hline M5 & 0.040 & 0.040 & 0.040 & 0.076 & 0 & & & & & & & & & & \\
\hline U1 & 0.428 & 0.428 & 0.428 & 0.379 & 0.379 & 0 & & & & & & & & & \\
\hline U2 & 0.428 & 0.357 & 0.428 & 0.310 & 0.379 & 0.125 & 0 & & & & & & & & \\
\hline U3 & 0.428 & 0.428 & 0.428 & 0.379 & 0.379 & 0.062 & 0.062 & 0 & & & & & & & \\
\hline U4 & 0.407 & 0.407 & 0.407 & 0.428 & 0.357 & 0.096 & 0.096 & 0.096 & 0 & & & & & & \\
\hline U5 & 0.428 & 0.357 & 0.428 & 0.379 & 0.379 & 0.187 & 0.062 & 0.062 & 0.096 & 0 & & & & & \\
\hline B1 & 0.379 & 0.379 & 0.379 & 0.333 & 0.333 & 0.090 & 0.151 & 0.090 & 0.187 & 0.151 & 0 & & & & \\
\hline B2 & 0.481 & 0.481 & 0.481 & 0.428 & 0.428 & 0.096 & 0.161 & 0.096 & 0.133 & 0.161 & 0.062 & 0 & & & \\
\hline B3 & 0.333 & 0.333 & 0.333 & 0.290 & 0.290 & 0.117 & 0.176 & 0.176 & 0.151 & 0.176 & 0.085 & 0.090 & 0 & & \\
\hline B4 & 0.333 & 0.333 & 0.333 & 0.285 & 0.285 & 0.161 & 0.225 & 0.161 & 0.266 & 0.225 & 0.062 & 0.133 & 0.151 & 0 & \\
\hline B5 & 0.360 & 0.360 & 0.360 & 0.307 & 0.307 & 0.172 & 0.310 & 0.241 & 0.285 & 0.310 & 0.133 & 0.142 & 0.161 & 0.071 & 0 \\
\hline
\end{tabular}

M, multivoltine (1-5 indicates individual from each population); U, univoltine (1-5 indicates individual from each population); B, bivoltine (1-5 indicates individual from each population).

ers showed univoltine and bivoltine populations difficult to distinguish but multivoltine population was always separated from these 2 ecotypes.

Like most molecular markers, the information content of an individual RAPD marker is very low. Ambiguous polymorphisms may result from poor discrimination by a primer between alternative priming sites of slightly different nucleotide sequences (Williams et al. 1990). RAPDs are dominant markers (Rafalski and
Tingey 1993) whose presence reflects priming sites flanking a segment of DNA suitable for amplification or codominant markers revealing insertions or deletions between priming sites (Mitton 1994). Results from RAPD analyses as done in this study may be usable in estimating the percentage of each ecotype in a population sample from a particular location. Because heterozygotes are not normally detectable, results are not readily usable for calculation of Hardy-

\section{$1 \mathrm{~kb} \mathrm{~m} 1 \mathrm{~m} 2 \mathrm{~m} 3 \mathrm{~m} 4 \mathrm{~m} 5 \mathrm{u} 1 \mathrm{u} 2 \mathrm{u} 3 \mathrm{u} 4 \mathrm{u} 5 \mathrm{~b} 1 \mathrm{~b} 2 \mathrm{~b} 3 \mathrm{~b} 4 \mathrm{~b} 550 \mathrm{bpCt}$}

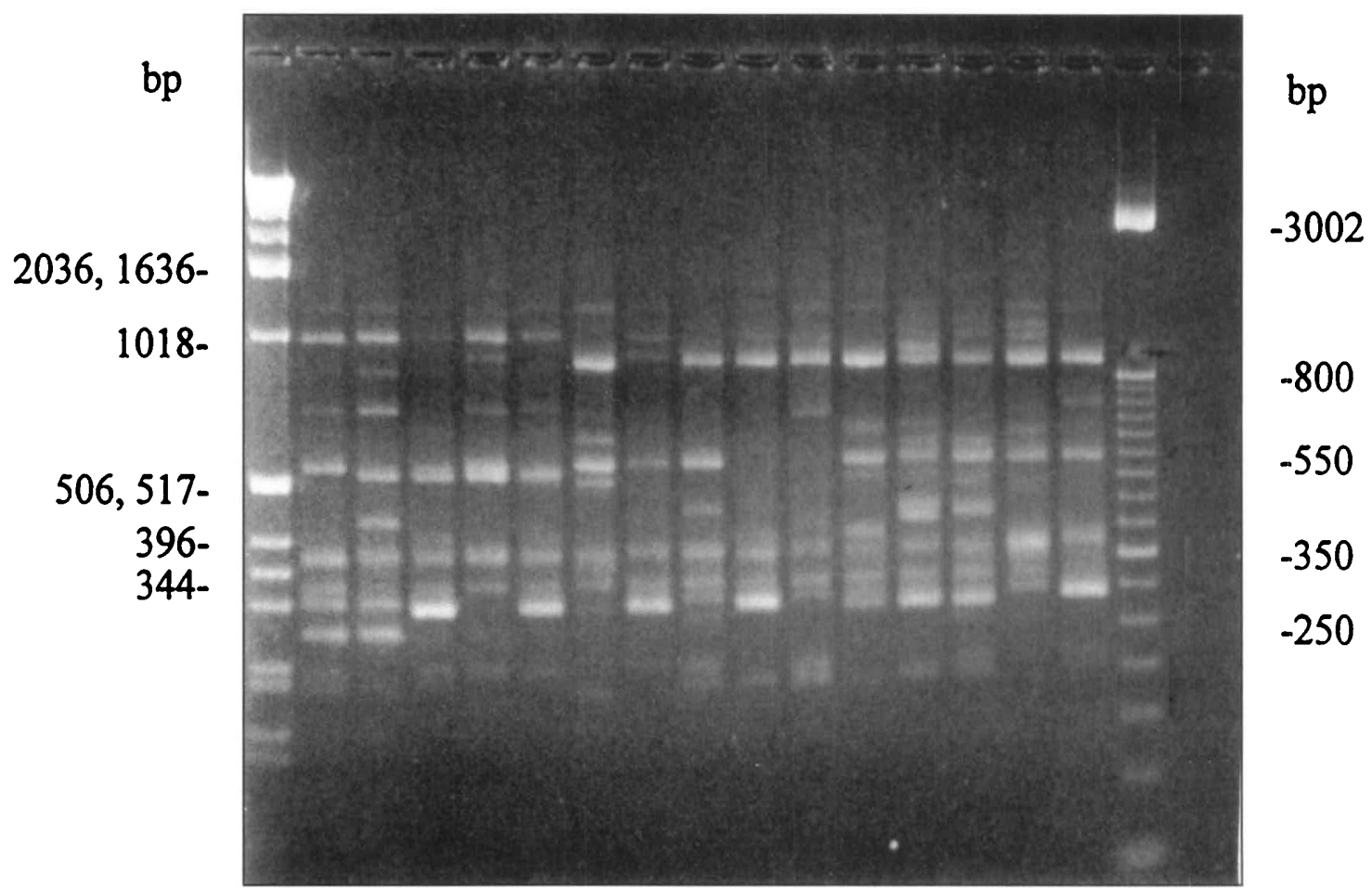

Fig. 1. Agarose gel patterns generated by RAPD primer OPB-01 showing intraspecific variation between ecotypes of European corn borer. Lane 1, 1-kb molecular weight ladder; lanes 2-6, multivoltine population; lanes 7-11, univoltine population; lanes 12-16, bivoltine population; lane 17, 50-bp molecular weight ladder; lane 18, negative control. 

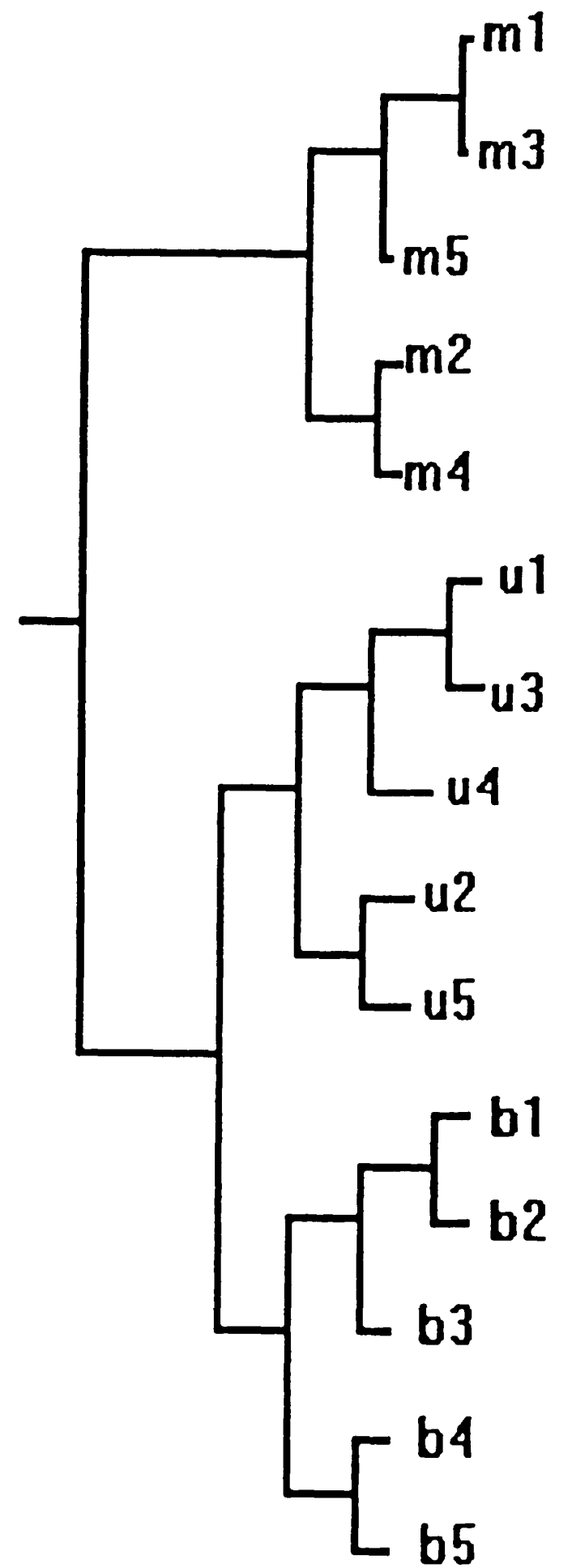

Fig. 2. The dendrogram, correctly classifying individuals in each ecotype of European corn borer, based on patterns of 21 RAPD markers from individuals used to construct a distance matrix (Nei and Li 1979) and then using unweighted pair groups using arithmetic averages: $\mathrm{ml}-\mathrm{m} 5$, multivoltine population; ul-u5, univoltine population; bl-b5, bivoltine population.

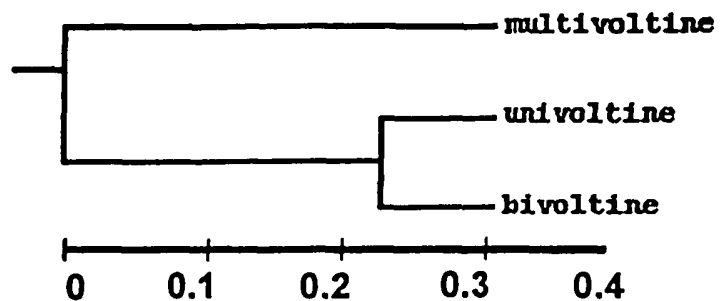

Fig. 3. The dendrogram constructed by using proportions of fragments in each ecotype to make a distance matrix (Nei 1972) and then using unweighted pair groups using arithmetic averages.

Weinberg gene frequencies (Lynch and Milligan 1994). Hence, RAPD markers alone cannot be used to predict European corn borer allele frequencies in a population.

It had been suggested that the outcome of a RAPD reaction was in part determined by a competition for priming sites in the genome (Williams et al. 1993). Amplification is probably initiated at many sites, but only a subset of all possible products is detected as visible bands after amplification (Halldén et al. 1996). In PCR, DNA with greater homology to the primer may be amplified at the expense of other DNA and some DNA may be preferentially amplified under specific conditions (Gibbs et al. 1989). This may be a reason why some individuals in our study, at the same molecular weight, produce a fainter band(s) compared with other individuals.

The RAPD-PCR technique is especially susceptible to contamination. Detecting contamination by including negative control reactions is essential (Pan et al. 1997). In our study, the PCR buffer, double distilled water, $\mathrm{MgCl}_{2}, \mathrm{PCR}$ tubes, and micropipettes were decontaminated with UV before use. Adding NP-40 can reduce the activity of inhibitor in the PCR mix. Our negative controls showed no contamination in most primers, or little contamination in some primers used. However, contamination did not affect the resulting pattern, because none of the bands in RAPD patterns matched the bands from control tubes (Meunier and Grimont 1993).

Optimization of all PCR mixes is crucial, ultimately making amplification more efficient. High on the list of optimization variables are $\mathrm{Mg}^{2+}$ concentrations, buffer $\mathrm{pH}$, and cycling conditions. With regard to the last variable, the annealing temperature is the most important (Roux 1995). Our results indicate that only bright DNA bands will be reliably amplified at all concentrations of DNA tested. In addition, only the GeneAmp PCR System 9600 was used to reduce the problem of variation among different machines that in turn caused some variation in the RAPD banding patterns.

The information from RAPD markers makes studies at the level of relatedness among ecotypes of European corn borer possible. Results from these RAPD patterns may be used to develop genetic maps for the European corn borer. RAPD markers have previously 
been used to develop linkage map for honey bees (Hunt and Page 1994). However most RAPD markers segregate as dominant alleles, reducing the amount of linkage information obtained. The efficiency of RAPD markers can be dramatically improved with the application of single-strand conformation polymorphism (SSCP) analysis. RAPD-SSCP was used to generate linkage maps in a haplodiploid parasitic wasp and a diploid mosquito (Antolin et al. 1996).

These results confirmed the applicability of this RAPD-PCR technique for evaluating genetic variation and developing markers in the European corn borer. Information from RAPD-PCR provides an indication of the baseline diversity present in the European corn borer. We demonstrated that RAPD fragments also could be used for identification and differentiation of European corn borer populations. An important question is whether RAPD bands of equal molecular weight that are shared between individuals are homologous characters (characters inherited from a common ancestor) or homoplastic characters (characters that arise independently within a population) (Tingey and Tufo 1993). Variation in RAPD patterns might be used as a diagnostic tool to identify unknown European corn borers collected from many locations in the United States or new strains that might develop in the future. Until then, we should be able to use RAPD to better understand if the variation between European corn borer populations is caused by dispersal or genetic shift.

\section{Acknowledgments}

We thank John Campbell (Pioneer Hi-Bred International) for providing us univoltine and bivoltine European corn borer, and James Overman (DeKalb Genetics Corp.) for multivoltine European corn borers. The assistance of Julie Ann Champoux and Valerie Wemhoff is greatly appreciated. This is Journal Series, paper 11965, Nebraska Agricultural Research Division, Institute of Agriculture and Natural Resources, University of Nebraska-Lincoln.

\section{References Cited}

Antolin, M. F., C. F. Bosio, J. Cotton, W. Sweeny, M. R. Stand, and W. C. Black IV. 1996. Intensive linkage mapping in a wasp (Bracon hebetor) and a mosquito (Aedes aegypti) with single strand conformation polymorphism analysis of random amplified polymorphic DNA markers. Genetics 143: 1727-1738.

Bengtsson, O. B., and C. Löfstedt. 1990. No evidence for selection in a pheromonally polymorphic moth population. Am. Nat. 136: 722-726.

Caffrey, D. J., and L. H. Worthley. 1927. A progress report on the investigations of the European corn borer. U.S. Dep. Agric. Dep. Bull. 1476.

Cardé, R. T., W. L. Roelofs, R. H. Harrison, A. T. Vawter, P. F. Brussard, A. Mutumera, and E. Munroe. 1978. European corn borer: pheromone polymorphism or sibling species? Science (Wash. D.C.) 199: 555-556.

[CIMMYT] Centro Internacional de Mejoramento de Maíz y Trigo. 1987. Toward insect resistant maize for the third world, pp. 46-59. In Proceedings of the International Symposium on Methodologies for Developing Host Plant
Resistance to Maize Insects, March 1987. CIMMYT, Mexico.

Felsenstein, J. 1989. PHYLIP_phylogeny inference package, version 3.2. Cladistics 5: 164-166.

Gibbs, R. A., P. Nguyen, and C. T. Caskey. 1989. Detection of single DNA base differences by competitive oligonucleotide priming. Nucleic Acids Res. 17: 2437-2448.

Glover, T. J., J. J. Knodel, P. S. Robbins, C. J. Eckenrode, and W. L. Roelofs. 1991. Gene flow among three races of European corn borers (Lepidoptera: Pyralidae) in New York State. Environ. Entomol, 20: 1356-1362.

Glover, T. J., P. S. Robbins, C. J. Eckenrode, and W. L. Roelofs. 1992. Genetic control of voltinism characteristics in European corn borer races assessed with a marker gene. Arch. Insect Biochem. Physiol. 20: 107-117.

Halldén, C., M. Hansen, N. O. Nilsson, A. Hjerdin, and T. Säll. 1996. Competition as a source of errors in RAPD analysis. Theor. Appl. Genet. 93: 1185-1192.

Hoy, M. A. 1994. Insect molecular genetics: an introduction to principles and applications. Academic, San Diego.

Hunt, J. G., and R. E. Page, Jr. 1994. Linkage map of the honey bee, Apis mellifera, based on RAPD markers. Genetics 139: 1371-1382.

Klun, J. A., P. L. Anglade, F. Bača, O. L. Chapman, H. C. Chiang, D. M. Danielson, W. Faber, P. Fels, R. E. Hill, M. Hudon, and others. 1975. Insect sex pheromones: intraspecific pheromonal variability of Ostrinia nubilalis in North America and Europe. Environ. Entomol. 4: 891894.

Klun, J. A., and S. Maini. 1979. Genetic basis of an insect chemical communication system: the European corn borer. Environ. Entomol. 8: 423-426.

Lynch, M., and B. L. Milligan. 1994. Analysis of population genetic structure with RAPD markers. Mol. Ecol. 3: 91-99.

Mason, C. E., M. E. Rice, D. D. Calvin, L. W. Van Duyn, W. B. Showers, W. D. Hutchison, J. F. Witkowski, R. A. Higgins, D. W. Onstad, and G. P. Dively. 1996. European corn borer ecology and management. N. Cent. Reg. Ext. Publ. 327.

Metcalf, R. L., and R. A. Metcalf. 1993. Destructive and useful insects: their habits and control. McGraw-Hill, New York.

Meunier, J. R., and P.A.D. Grimont. 1993. Factors affecting reproducibility of random amplified polymorphic DNA fingerprinting. Res. Microbiol. 144: 373-379.

Mitton, J. B. 1994. Molecular approaches to population biology. Annu. Rev. Ecol. Syst. 25: 45-69.

Nei, M. 1972. Genetic distance between populations. Am. Nat. 106: 283-293.

Nei, M., and W. H. Li. 1979. Mathematical model for studying genetic variation in terms of restriction endonucleases. Proc. Natl. Acad. Sci. U.S.A. 76: 5269-5273.

Pan, Y. B., D. M. Burner, K. C. Ehrlich, M. P. Grisham, and Q. Wei. 1997. Analysis of primer derived, nonspecific amplification products in RAPD-PCR. BioTechnology 22: $1071-1077$.

Rafalski, J. A., and S. V. Tingey. 1993. Genetic diagnostics in plant breeding: RAPDs, microsatellites and machines. Trends Genet. 9: 270-280.

Ragot, M., and D. A. Hoisington. 1993. Molecular markers for plant breeding: comparisons of RFLP and RAPD genotyping costs. Theor. Appl. Genet. 86: 975-984.

Roderick, G. K. 1996. Geographic structure of insect populations: gene flow, phylogeography, and their uses. Annu. Rev. Entomol. 41: 325-352.

Roux, K. H. 1995. Optimization and troubleshooting in PCR. PCR Primer: a laboratory manual. Cold Spring Harbor Laboratory, Cold Spring Harbor, NY. 
Schnell, R. J., P. M. Madiera, M. K. Hennessey, and J. L. Sharp. 1996. Inheritance of random amplified polymorphic DNA markers in Anastrepha suspensa (Diptera: Tephritidae). Ann. Entomol. Soc. Am. 89: 122-128.

Showers, W. B., H. C. Chiang, A. J. Keaster, R. E. Hill, G. L. Reed, A. N. Sparks, and G. J. Musick. 1975. Ecotypes of the European corn borer in North America. Environ. Entomol. 4: 753-760.

Tingey, S. V., and J. P. del. Tufo. 1993. Genetic analysis with random amplified polymorphic DNA markers. Plant Physiol. 101: 349-352.

Welsh, J., and M. McCelland. 1990. Fingerprinting genomes using PCR with arbitrary primers. Nucleic Acids Res. 18: 7213-7218.

Williams, J.G.K., A. R. Kubelik, K. J. Livak, J. A. Rafalski, and S. V. Tingey. 1990. DNA polymorphisms amplified by arbitrary primers are useful as genetic markers. Nucleic Acids Res. 18: 6531-6535.

Williams, J.G.K., M. K. Hanafey, J. A. Rafalski, and S. V. Tingey. 1993. Genetic analysis using random amplified polymorphic DNA markers. Methods Enzymol. 218: 704 740.

Zhu, J., C. Löfstedt, and B. O. Bengtsson. 1996. Genetic variation in the strongly canalized sex pheromone communication system of the European corn borer, Ostrinia nubilalis Hübner (Lepidoptera: Pyralidae). Genetics 144: 757-766.

Received for publication 22 December 1997; accepted 16 March 1998. 